\title{
IMPACTOS DO AGRONEGÓCIO FLORESTAL NO TERRITÓRIO CAMINHOS DO TIBAGI - PR
}

\section{INFLUENCE OF FOREST AGRIBUSINESS ON THE TERRITÓRIO CAMINHOS DO TIBAGI - PR}

\begin{abstract}
Guilherme Pedrollo Mazer Mestrado em Agroecologia e Desenvolvimento Rural Sustentável pela Universidade Federal da Fronteira Sul, Extensionista do Laboratório de Mecanização Agrícola da Universidade Estadual de Ponta Grossa, Ponta Grossa, PR, Brasil guiguemazer@gmail.com

Pedro Ivan Christoffoli Doutorado em Desenvolvimento Sustentável pela Universidade de Brasília, Professor do Programa de Pós-Graduação em Agroecologia e Desenvolvimento Rural Sustentável da Universidade Federal da Fronteira Sul, Coordenador do Núcleo de Estudos em Cooperação, Laranjeiras do Sul, PR, Brasil pedroivanc@uffs.edu.br
\end{abstract}

\begin{abstract}
Resumo
O agronegócio florestal tem avançado no Território Caminhos do Tibagi, no Paraná, impondo um modelo de exploração hegemônico das terras, visando o lucro para um grupo reduzido de pessoas. Esse modelo está inserido no processo histórico de exploração desse território pelas classes dominantes, com sustentação estatal. Esse modelo de desenvolvimento e ocupação do território resulta em uma série de impactos socioeconômicos e ambientais. Os territórios camponeses resistem e apresentam alternativas para outro modelo de desenvolvimento do território.
\end{abstract}

Palavras-chave: Agronegócio. Território Caminhos do Tibagi. Territórios camponeses.

\begin{abstract}
Forest agribusiness has advanced in the Território Caminhos do Tibagi, imposing a hegemonic model of land exploitation, aiming at profit for a small group of people. This model is inserted in the historical process of exploitation of this territory by the ruling classes, with state support. This model of development and occupation of the territory results in a series of socioeconomic and environmental impacts. Peasant territories resist and present alternatives to another model of territorial development.
\end{abstract}

Keywords: Agribusiness. Caminhos do Tibagi Territory. Peasant territories. 


\section{Introdução}

Este artigo analisa como o agronegócio florestal tem avançado no Território Caminhos do Tibagi, no Paraná, e de que maneira tem impactado socioeconomicamente e ambientalmente este Território. O ponto de partida é uma análise de como o Estado e a geopolítica do setor influenciaram o avanço do setor agroflorestal. Em seguida, buscouse elementos relacionados às questões ambientais e socioeconômicas, para analisar os impactos que o setor promove no Território. E, por fim, analisa-se a disputa do território material e imaterial através dos dois modelos de desenvolvimento em curso, o do agronegócio florestal e dos camponeses. As informações para essas análises foram extraídas através de dados secundários, Sistema de Informação Geográfica (SIG), entrevistas e vivência dos autores. O texto base e os dados utilizados fazem parte de dissertação de mestrado de um dos autores (MAZER, 2018).

\section{O papel do Estado na constituição do complexo florestal e industrial da celulose no}

\section{Brasil}

A indústria de papel e celulose desenvolveu-se inicialmente na Grã-Bretanha, França e Alemanha, dominando a indústria de papel no início da produção mecanizada. Esse domínio, na última metade do século XIX e no século XX, passa para a América do Norte e os Países Nórdicos. Com a utilização da fibra de madeira para produção de celulose, as vastas áreas florestais com coníferas dessas regiões justificavam a escolha desses locais para produção de papel em larga escala, por questões técnicas e econômicas (TOIVANEN, 2012).

$\mathrm{Na}$ virada do milênio, o domínio da indústria de papel deslocou-se para o hemisfério sul e para a Ásia Oriental, acompanhando assim as tendências internacionais da globalização industrial. Segundo Ojala et al. (2013), mercado, procura e suprimento de matérias-primas são fatores significativos para explicar a evolução desse segmento industrial nos respectivos países. Isso mostra que, para a localização geográfica do domínio da indústria de papel e celulose, a disponibilidade de matéria-prima é fator determinante. O deslocamento do domínio geográfico da indústria para América do Sul e Sul da Europa, na década de 1990, se deve muito à utilização do eucalipto para obtenção da celulose. No Brasil, o eucalipto foi introduzido em 1864, com a finalidade de produzir 
dormentes de estradas de ferro e carvão para as locomotivas. Contudo seu uso para produção de celulose não se desenvolveu até a Segunda Guerra Mundial por limitações tecnológicas (LIMA-TOIVANEN, 2013).

O setor industrial de papel brasileiro começa a deslanchar na década de 1950 ao investir em pesquisas e desenvolvimento da cultura de eucalipto para obtenção de celulose e principalmente por estímulos econômicos governamentais. Com a meta de autossuficiência nacional em celulose e madeira até 1960, a escassez global de celulose e os aumentos sucessivos dos preços do produto no mercado, o BNDES começa a criar instrumentos de financiamento para o setor, visando economia de escala e aprimoramento tecnológico da indústria. O resultado dessas políticas foi o aumento da participação de fibras curtas, quase unicamente de eucalipto, para produção de celulose, de 4\% em 1950 para 60\% em 1960 (LIMA-TOIVANEN, 2013).

O BNDES também passou a induzir, em 1968, que as indústrias obtivessem pelo menos metade de sua celulose através de recursos florestais próprios, e que aprimorassem tecnologias relacionadas ao eucalipto e aos diversos tipos de papel. O mesmo banco motivou a organização nacional de normas técnicas através da ABNT (Associação Brasileira de Normas Técnicas). Em relação à área institucional, o Estado estabeleceu incentivos fiscais ao reflorestamento industrial, e com o Código Florestal de 1965 permitiu o uso em larga escala de eucalipto e pinheiro, com dedução de impostos sobre essas plantações.

De 1971 a 1974, os reflorestamentos triplicaram em relação ao período de 1967 a 1970. Em 1974, foi aprovado o Plano de Ação para 1974 a 1978, estabelecendo prioridade de estímulo para os projetos que tinham por objetivo a exportação, originando o II Plano Nacional de Desenvolvimento (PND), no qual foi elaborado o I Programa Nacional de Papel e Celulose (IPNPC). Previa-se autossuficiência em papel e celulose, com geração de excedentes de celulose para exportação (HILGEMBERG; BACHA, 2001).

O surgimento, desde os anos 1950, da chamada "modernização conservadora" levaria, com o golpe de 1964, à derrota da Reforma Agrária como eixo estratégico de desenvolvimento. No período que vai até 1980, até então considerados os anos dourados do desenvolvimento, se consolida um novo padrão para uma agricultura capitalista, calcado em pesados subsídios governamentais. A modernização conservadora foi denominada por Delgado (2001) como um processo de integração técnica da agricultura- 
indústria, pela crescente presença de insumos industriais e alteração na base técnica dos meios de produção utilizados e máquinas industriais. Também ocorreu uma integração entre a produção primária de alimentos e matérias-primas, assim como vários ramos industriais, inclusive de papel e celulose.

As técnicas agrícolas, que eram rudimentares, com a Revolução Verde deram lugar ao "pacote tecnológico", impulsionado pelo sistema público de pesquisa (Embrapa) e extensão rural (Embrater), que pode ser resumido pelo uso de variedades de plantas melhoradas geneticamente, com potencial produtivo atrelado ao uso de fertilizantes sintéticos, agrotóxicos e motomecanização (MAZOYER; ROUDART, 2010). A produção agrícola passou a ocupar lugar importante no mercado, como comprador de insumos e tecnologia, fornecedor de matéria-prima para indústria e alimentos para os crescentes centros urbanos (SILVA, 2003; ROSTOW, 1959), ganhando mais tarde a denominação de agronegócio.

O camponês continuou à margem da modernização tecnológica. Os efeitos negativos da Revolução Verde não se deram pela adoção das novas tecnologias em si, mas principalmente pela desigualdade estrutural existente nos países capitalistas subdesenvolvidos. A grande propriedade tinha maior capacidade de reter ganhos de produtividade e produção de larga escala, acesso a crédito, controlava a comercialização e, sobretudo, influía nas políticas públicas do setor agrícola. Essa nova realidade acabou por agravar, na década de 1970, a pré-existente concentração fundiária e desigualdade no meio rural (HOFFMAN; KAGEYAMA, 1985).

No período, foram criados o Sistema Nacional de Crédito Rural, Programa de Garantia da Atividade Agropecuária (Proagro), Política de garantia de preço, além de incentivos fiscais como desoneração do Imposto de Renda e Imposto Territorial Rural. Não há como negar o incremento dos índices tecnológicos, de produção e diversificação do período, como também não se pode negar que ele foi fundamentado em incentivos fiscais e financeiros por parte do Estado no setor rural (DELGADO, 2001).

A crise econômica dos anos 80 e a transição para liberalização da agricultura dos anos 90 acabaram limitando os incentivos fiscais para agricultura de maneira geral. Ainda assim, em 1987, o governo federal lançou outro Programa Nacional de Papel e Celulose (II PNPC), incentivando uma vez mais a expansão e modernização do setor. Nesse 
período, em média $69,26 \%$ da quantidade produzida de papéis foi destinada à venda doméstica e somente 14,54\% às exportações (MONTEBELLO, 2013).

Com a abertura comercial dos anos 1990, a ruptura da política econômica de substituição de importações e a retirada de capital Estatal financiando o investimento da indústria, o setor passa por uma reconfiguração. Seguindo a lógica do contexto de globalização, a indústria de papel e celulose acompanhou a tendência mundial desse período de reestruturação patrimonial, através da concentração produtiva por meio de fusões e aquisições de grandes empresas, com objetivo de redução de custo para ter mais competitividade no mercado internacional. Em 1980, existiam 47 empresas de celulose no Brasil, e em 1999 existiam apenas 11; no mesmo período, as empresas de papel passaram de 172 para 83, e de artefatos de papel de 988 para 244. Esse processo de fusões se aprofundou depois dos anos 2000 visando o mercado internacional, com uma interrelação entre os grandes grupos, e com o BNDES fazendo parte do controle acionário das grandes empresas (MONTEBELLO, 2013).

Na década de 1990, a vantagem competitiva pelos custos de produção do Brasil em relação aos outros países produtores de celulose é demonstrada por Fonseca (1995). A favor do Brasil relacionou-se os custos inferiores de energia, produtos químicos e mãode-obra. Além disso, os ganhos de produtividade na atividade de reflorestamento.

\section{A constituição do complexo industrial da celulose do Grupo Klabin no Paraná}

A empresa Klabin se instala no território conhecido atualmente como Território Caminhos do Tibagi em 1934, com a compra da Fazenda Monte Alegre. Constituem o Território Caminhos do Tibagi nove municípios: Curiúva, Figueira, Imbaú, Ortigueira, Reserva, Telêmaco Borba, Tibagi, Ventania e Tamarana. O Território localiza-se no Segundo Planalto Paranaense e tem uma área de $10.664,14 \mathrm{~km}^{2}$ (Figura 1). Grande parte dele está inserida na região dos Campos Gerais, e, portanto, o processo de ocupação dessa região determina, em certa medida, o processo de ocupação do Território. 
Figura 1: Localização do Território Caminhos do Tibagi
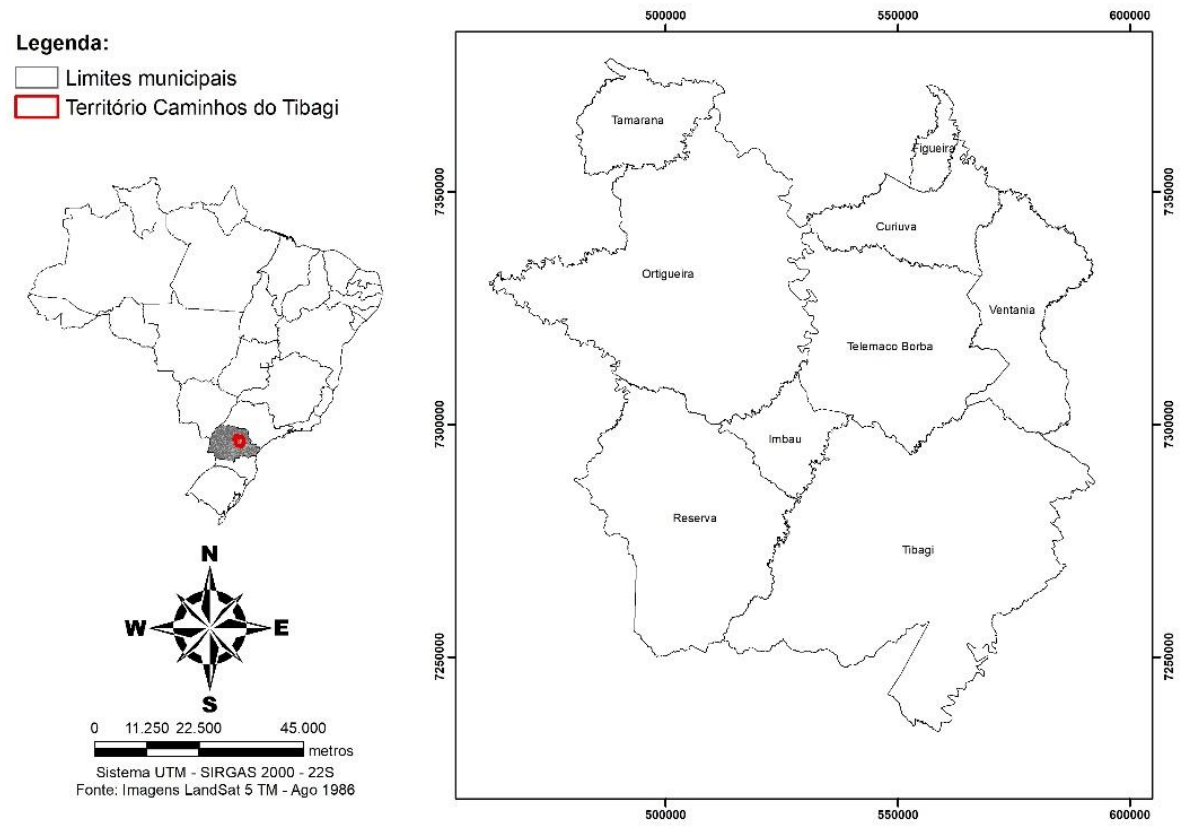

Fonte: IPARDES, 2007.

Org.: MAZER, 2018.

A parcela dos Campos Gerais onde está inserido o Território Caminhos do Tibagi, diferentemente do restante dos Campos Gerais, hoje tem suas atividades econômicas polarizadas pela grande indústria papeleira alocada principalmente no Município de Telêmaco Borba (IPARDES, 2007). A Fazenda Monte Alegre foi originada no período de concessão das sesmarias, quando José Felix da Silva recebeu da Coroa 65.000 alqueires de terra (maior sesmaria da região) pelo massacre de indígenas da etnia Kaingangue. Em 1932 a fazenda foi tomada em garantia de dívida pelo Banco do Estado do Paraná, que posteriormente, em 1934, a repassa à Klabin. (CUNHA, 1982). O Estado do Paraná tinha como desafio expandir novas áreas econômicas, razão pela qual seguiu as diretrizes do Estado Novo, iniciando políticas industrializantes (OLIVEIRA, 1997). Em paralelo, o Governo Federal atuava sob a perspectiva de substituição de importações, tornando relevantes as demandas do setor da imprensa e indústria de papel (MARGALHO, 2008). Para viabilizar o projeto Klabin, o Governo do Estado do Paraná se comprometeu com investimento na construção de estradas e ramais ferroviários, e o Governo Federal se responsabilizou concedendo benefícios fiscais creditícios e empréstimos para viabilizar a construção do complexo industrial. O Banco do Brasil atuou como um dos grandes financiadores do projeto (MARGALHO, 2008). 
A Segunda Guerra Mundial trouxe uma conjuntura favorável ao grupo empresarial devido ao aumento de custos de importação de papel imprensa e celulose, fazendo com que Vargas estimulasse o setor através de apoio estatal (MARGALHO, 2008). Em 1945, com uma nova fábrica, foi iniciada a fabricação de celulose sulfite, e em 1946 de celulose kraft, com uma produção de 75 toneladas por dia. Em 1947, é inaugurada a Usina Hidrelétrica de Mauá, e iniciada a produção de papel jornal, vindo atender no mesmo ano os jornais das cidades de Curitiba, São Paulo e Rio de Janeiro (CUNHA, 1982). Numa imbricação política-economia Horácio Lafer, um dos sócios do grupo empresarial, foi eleito deputado em 1946 e, com o fim do Estado Novo, é indicado para o Ministério da Fazenda, de 1951 a 1953, durante o segundo Governo Vargas (MARGALHO, 2008). Esse fato exemplifica, de forma particular, a consolidação do projeto de hegemonia da burguesia industrial, participando do bloco dirigente do Estado Capitalista pós 1950. E o projeto específico da Klabin, obviamente, ganha impulso.

Os investimentos do Estado em pesquisas e crédito para o avanço da silvicultura com vistas à obtenção de celulose foram igualmente importantes para o grupo Klabin. Atualmente e até um passado recente a atuação do Estado vem beneficiando de maneira preponderante esse modelo de desenvolvimento. No Território, desde 1984 a Klabin mantém o Programa de Fomento Florestal, que até o final dos anos 2000 contava com parceria junto à EMATER-PR. No início, a Klabin doava as mudas aos agricultores e a EMATER se incumbia de dar as orientações técnicas, para que as propriedades tivessem até no máximo $20 \%$ de áreas de eucalipto para usos múltiplos. A contrapartida da Klabin junto ao Estado no convênio foi a doação de quatro carros, conforme relatado pelo Engenheiro Agrônomo da EMATER do Município de Reserva, Marcelo Hupalo (2018).

Após 2008, iniciaram-se duas modalidades de fomento. Uma consistia no pagamento das mudas quando da comercialização da madeira para a empresa, e outra através do Pronaf, com a empresa de avalista do empréstimo. É sempre relatado pelos agricultores do Território que nesse período houve muito interesse no plantio de eucalipto através dessas modalidades de fomento, pois culminava com o período de corte daquelas mudas doadas, para, segundo a Klabin (2017), diversificar as atividades agrícolas das comunidades, e o agricultor recebia um valor aparentemente alto pela madeira no corte, não fazendo os cálculos da rentabilidade da madeira durante todo o período. 
Em 2006, o BNDES aprovou empréstimo de R\$ 1,74 bilhão para a Klabin S.A. aumentar a capacidade de produção da Fábrica Monte Alegre, em Telêmaco Borba (BNDES, 2006). Já em 2016, o BNDES financiou 54\% (R \$ 3,37 bilhões) do valor da nova fábrica da Klabin em Ortigueira, a Puma (BNDES, 2016).

Em contraposição, no período de 2003 a 2014, o Governo Federal apoiou 22 projetos de infraestrutura da agricultura familiar/camponesa no Território Caminhos do Tibagi, através do Programa de Apoio a Projetos de Infraestrutura e Serviços em Territórios Rurais (Proinf), totalizando apenas R\$ 2,3 milhões (SDT/MDA, 2015). Esse desbalanço de investimentos por parte do Estado foi a tônica no sentido do direcionamento das políticas de desenvolvimento, que favoreceram o modelo do agronegócio em detrimento da agricultura familiar.

O investimento estatal está no conjunto de fatores que alavancaram significativamente a disponibilidade de matéria-prima nas proximidades da fábrica, como pode se observar na Tabela 1, e sua influência sobre o território através da dependência dos agricultores em comercializar sua produção com a empresa. Com mais oferta de matéria-prima no território, a empresa tem mais controle sobre os preços da madeira (visto produzir parte de suas necessidades), podendo assim diminuir seu custo de produção através regulação de preços e da diminuição do custo de insumos.

Tabela 1: Reflorestamento no Território Caminhos do Tibagi em 1986, 2001 e 2016

\begin{tabular}{|c|c|c|c|c|c|c|c|}
\hline \multirow{2}{*}{ Municípios } & \multirow{2}{*}{$\begin{array}{l}\text { Área total } \\
\text { território(ha) }\end{array}$} & \multicolumn{2}{|c|}{$\begin{array}{l}\text { Reflorestamento } \\
1986\end{array}$} & \multicolumn{2}{|c|}{$\begin{array}{l}\text { Reflorestamento } \\
2001\end{array}$} & \multicolumn{2}{|c|}{$\begin{array}{l}\text { Reflorestamento } \\
2016\end{array}$} \\
\hline & & Área (ha) & $\%$ & Área (ha) & $\%$ & Área (ha) & $\%$ \\
\hline Curiúva & 57.626 & $5.424,07$ & $9,41 \%$ & $5.250,00$ & $9,11 \%$ & $7.452,82$ & $12,93 \%$ \\
\hline$\overline{\text { Figueira }}$ & 12.977 & 205,44 & $1,58 \%$ & 313,53 & $2,42 \%$ & $1.268,57$ & $9,78 \%$ \\
\hline Imbaú & 33.070 & $2.037,42$ & $6,16 \%$ & $7.919,24$ & $23,95 \%$ & $8.447,03$ & $25,54 \%$ \\
\hline Ortigueira & 242.956 & $4.374,70$ & $1,80 \%$ & $10.988,60$ & $4,52 \%$ & $19.868,04$ & $8,18 \%$ \\
\hline Reserva & 163.352 & $1.946,28$ & $1,19 \%$ & $11.047,73$ & $6,76 \%$ & $17.842,56$ & $10,92 \%$ \\
\hline Tamarana & 47.053 & 602,72 & $1,28 \%$ & 287,54 & $0,61 \%$ & 636,40 & $1,35 \%$ \\
\hline $\begin{array}{l}\text { Telêmaco } \\
\text { Borba } \\
\end{array}$ & 138.286 & $56.346,02$ & $40,75 \%$ & $69.493,86$ & $50,25 \%$ & $62.792,42$ & $45,41 \%$ \\
\hline Tibagi & 295.157 & $11.851,79$ & $4,02 \%$ & $29.648,75$ & $10,05 \%$ & $27.580,15$ & $9,34 \%$ \\
\hline Ventania & 75.937 & $5.105,26$ & $6,72 \%$ & $7.364,05$ & $9,70 \%$ & $11.842,3$ & $15,59 \%$ \\
\hline Total & 1.066 .414 & $87.893,70$ & $8,24 \%$ & $142.313,30$ & $13,35 \%$ & $157.730,29$ & $14,79 \%$ \\
\hline
\end{tabular}

Fonte: Landsat 5, Landsat 7, Landsat 8, 1986, 2011 e 2016.

Org: MAZER,2018 
Como se pode perceber, nos últimos 30 anos, com exceção de Telêmaco Borba que manteve estável o uso do solo destinado ao reflorestamento de exóticas devido à exploração dessa atividade já estar em sua capacidade espacial máxima, e do município de Tamarana, por não estar na zona de influência da Klabin, todos os outros municípios do Território Caminhos do Tibagi apresentaram relevante aumento de reflorestamento em suas áreas. O padrão de avanço espacial do agronegócio florestal é muito mais influenciado pelos limites que o espaço pode proporcionar em razão do aumento do custo operacional do que pelos limites administrativos, conforme Figura 2, Figura 3 e Figura 4.

Figura 2: Reflorestamento de exóticas no Território Caminhos do Tibagi em 1986

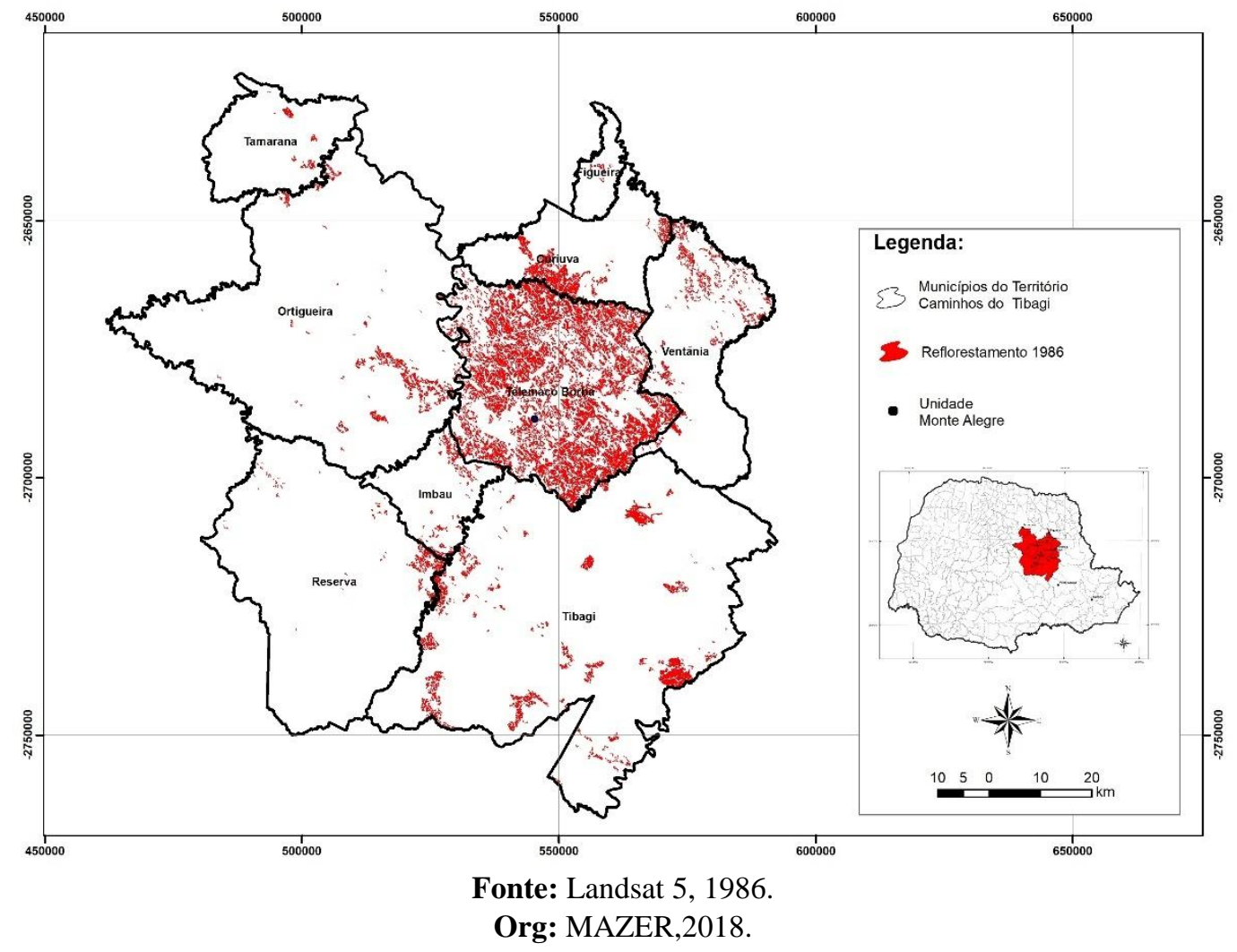


Figura 03: Reflorestamento de exóticas no Território Caminhos do Tibagi em 2001

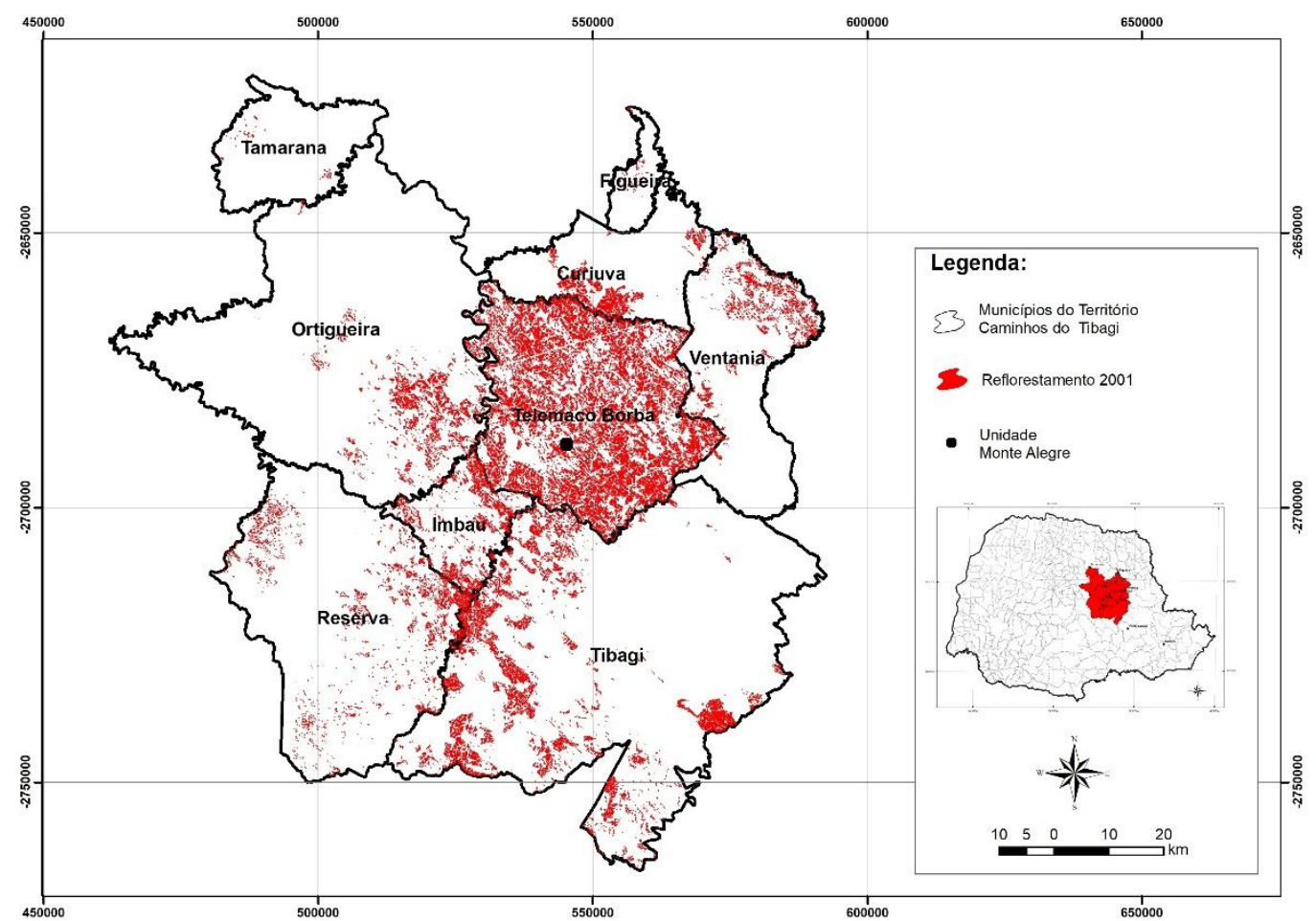

Fonte: Landsat 7, 2001.

Org: MAZER, 2018.

Figura 4: Reflorestamento de exóticas no Território Caminhos do Tibagi em 2016

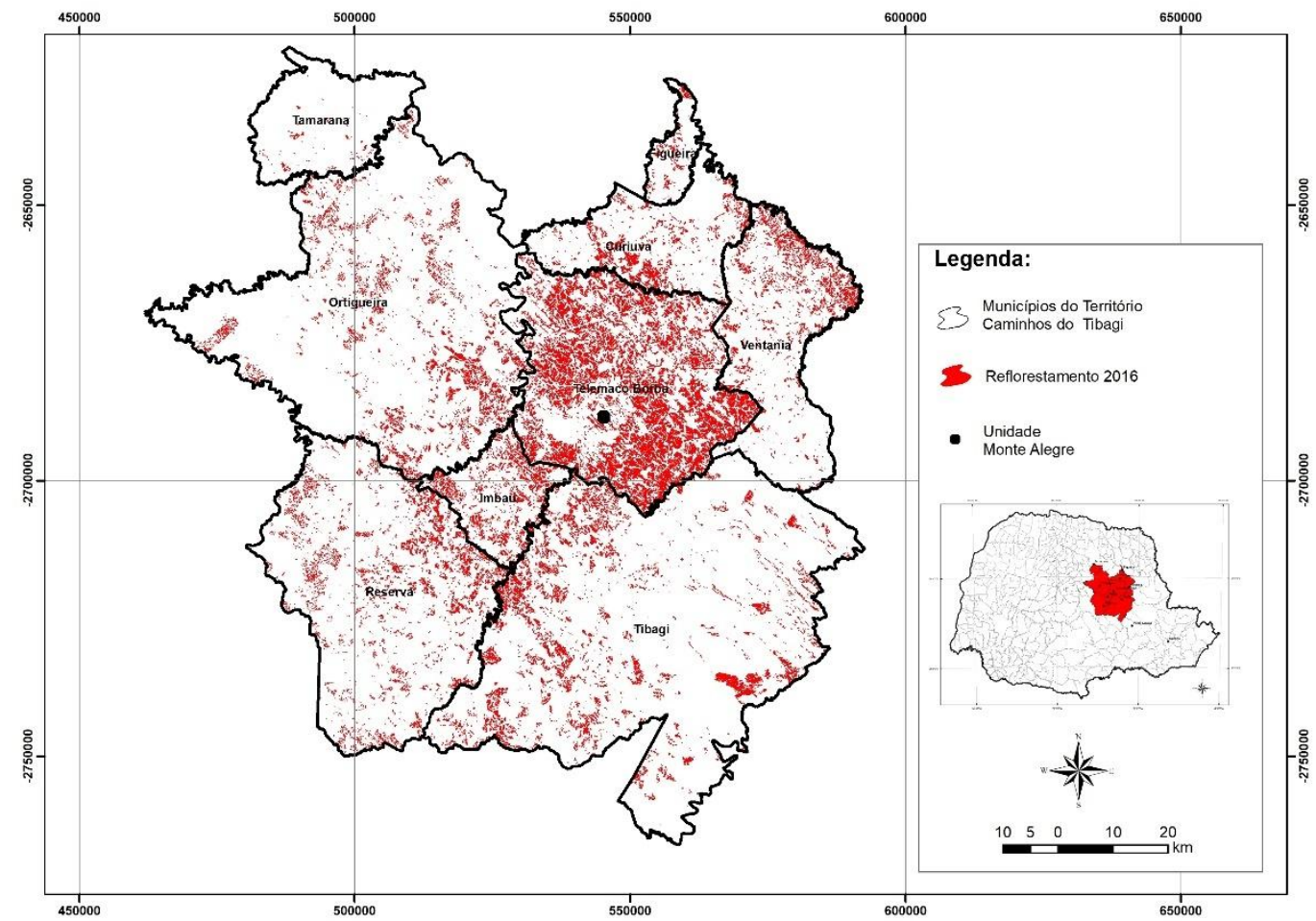

Fonte: Landsat 8, 2016.

Org: MAZER,2018. 
Pode ser observado que essa estratégia coordenada de expansão do reflorestamento faz parte das políticas da empresa (KLABIN, 2017), sendo que os reflorestamentos que abastecem a fábrica no Paraná se encontram numa média de 66 km, o que lhes garante vantagem competitiva.

\section{Impactos ambientais do agronegócio florestal da Klabin}

O avanço significativo do plantio industrial de florestas territorializa o agronegócio florestal a partir de sua dinâmica econômica, reorganizando seus arranjos produtivos, sociais, institucionais e simbólicos. É mais do que exploração simples da terra e seus recursos naturais, é a completa reconfiguração de um amplo território a partir dos interesses do capital. Ainda mais, o agronegócio florestal tenta significar esse modelo de exploração do território como sendo um modelo de desenvolvimento sustentável.

O interesse inicial da Klabin era atrelado à vasta quantidade de Pinheiros do Paraná, que poderia ser usada como fonte de matéria-prima para obtenção da celulose. A primeira preocupação em relação ao uso dos recursos florestais pela Klabin partiu do Estado. O Instituto Nacional do Pinho, fundado em 1941, chamou a atenção de seus membros sobre a possibilidade de um grupo privado deter 144.000 alqueires com farta presença de pinheiros, uma vez que o Instituto estava com a incumbência da preservação dos recursos naturais, principalmente em relação ao pinheiro, por ser matéria-prima estratégica de vários setores, e com demanda se ampliando no cenário da Segunda Guerra (MARGALHO, 2008).

A preocupação que outrora era referente à conservação dos recursos naturais por motivos principalmente econômicos, voltados à soberania da indústria nacional, atualmente se revela relevante (FIGURA 5) e se transforma em preocupações ambientais, uma vez que a indústria não necessita mais de espécies nativas (em sua maioria devastada) como fonte de matéria-prima. O Território Caminhos do Tibagi está inserido no Bioma da Mata Atlântica, que vem sofrendo com a pressão das monoculturas em todo Brasil. 
Figura 5: Mapa de reflorestamento inserido nos Domínios Fitogeográficos do Bioma Mata Atlântica no Território Caminhos do Tibagi em 2016

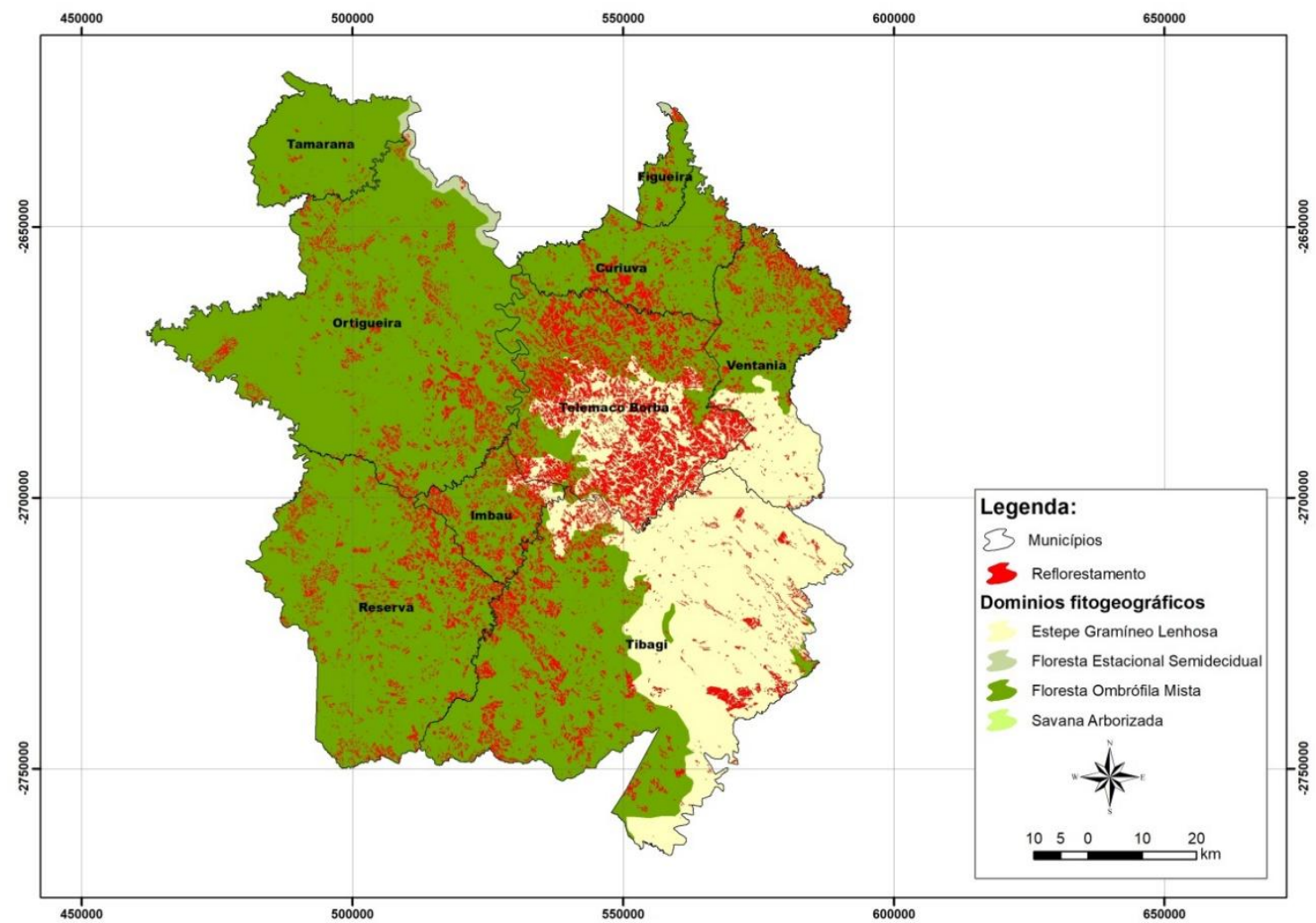

Fonte: Landsat 8, 2016.

Org: MAZER,2018.

Na Figura 5 pode-se observar que a maior parte do Território era constituída originalmente por Floresta Ombrófila Mista (811.254 hectares), e uma grande porção de Estepe Gramíneo Lenhosa, áreas de Campo Nativo (254.984 hectares). Também conta com uma porção bastante reduzida mais ao norte de Floresta Estacional Semidecidual (6.786 hectares) e um pedaço muito pequeno de Savana Arborizada, Relíquito de Cerrado (998 hectares). A maior área de reflorestamento está situada na Floresta Ombrófila Mista (109.920 hectares), substituindo 13\% desse domínio fitogeográfico por reflorestamento. A maior proporção de reflorestamento dentro dos domínios se dá nas áreas de Campo, onde $18 \%$ dessa vegetação hoje é de reflorestamento.

Por mais que se tente transmitir uma ideia de que o reflorestamento de eucalipto evita desmatamentos, a atividade foi responsável pela devastação de parte da vegetação nativa existente originalmente de maneira quase que irreversível e tem implicações preocupantes. No caso do Território, uma grande preocupação se dá com a Estepe 
Gramíneo Lenhosa, principalmente por estar sendo suprimida quase que completamente com atividades de reflorestamento e ter várias espécies endêmicas em extinção.

Em razão dos ciclos da erva mate e da madeira, as florestas com araucária na região dos Campos Gerais foram muito exploradas, sendo que atualmente o seu remanescente está em estágio de equilíbrio secundário. Isso é resultado do processo de regeneração que vem ocorrendo há aproximadamente 50 anos, que, por sua vez, decorre principalmente do avanço tecnológico e da diminuição de extração de material lenhoso (MORO, 2001). Desse modo, não há uma presença representativa de remanescentes intocados na maior parte dos capões mais desenvolvidos, posto que estes foram profundamente alterados (RODERJAN et al., 2002; CASTELLA; BRITEZ, 2004).

Noutro passo, não se pode afirmar que somente a monocultura dos reflorestamentos de árvores exóticas é responsável pela supressão da vegetação nativa e biodiversidade. O modelo de agricultura de larga escala, independente da cultura agrícola, também provoca impactos ambientais severos aos ecossistemas. Porém, no caso do Território Caminhos do Tibagi, pode-se asseverar que os reflorestamentos da Klabin no município de Telêmaco Borba substituíram os campos nativos de 68.139 hectares desse domínio fitogeográfico, restando apenas as matas de galeria.

Nos últimos anos surgiu um conflito intenso entre os interesses do agronegócio florestal e a preservação dos últimos fragmentos de campo na Região dos Campos Gerais. Na borda leste do Território Caminhos do Tibagi se encontra uma unidade de conservação que pode ser considerada um dos últimos refúgios dessa vegetação, a Área de Preservação Ambiental (APA) da Escarpa Devoniana. Existe forte pressão dos setores ligados ao agronegócio para reduzir a área dessa unidade de conservação a fim de legalizar a exploração de atividades agrícolas nesse Território.

Ressalta-se que o modelo dominante de agricultura brasileiro é responsável por colocar o país como o maior consumidor de agrotóxicos do mundo em números absolutos. A Klabin considera satisfatório, em seus relatórios, ter utilizado em suas plantações, no ano de 2016, 0,20 $\mathrm{kg} \mathrm{ha}^{-1}$ de herbicidas, 1,43 $\mathrm{L} \mathrm{ha}^{-1}$ também de herbicida e 2,85 $\mathrm{kg} \mathrm{ha}^{-1} \mathrm{de}$ formicida (KLABIN, 2017). Se extrapolarmos essa média de consumo de agrotóxicos para os 157.730,29 hectares de reflorestamento de exóticas no Território Caminhos do Tibagi, tem-se um consumo de 31,54 toneladas de herbicidas, mais 225.554 litros de 
herbicidas e 449,53 toneladas de formicidas contaminando o solo, a água e o ar do território.

\section{Impactos socioeconômicos}

A agroindústria da celulose e a silvicultura criam a possibilidade de inserção de diversas regiões em escalas econômicas, nacional e internacional, e, em contrapartida, são promotoras de relevantes impactos socioeconômicos no meio rural. A expansão do agronegócio florestal com objetivo de suprir as indústrias de papel e celulose acaba, de certa maneira, rompendo as estruturas socioprodutivas tradicionais. Os novos processos técnicos introduzidos pelo agronegócio florestal fazem emergir novas relações sociais e políticas (PEDREIRA, 2004).

O processo de liberalização comercial do setor da celulose nos últimos vinte anos colocou entre suas características mais marcantes uma mudança no controle societário das empresas, fundamentado no controle compartilhado entre sócios nacionais e estrangeiros e formação entre grupos nacionais, acelerando os processos de fusão e aquisição. Outra característica relevante foi o aumento da produtividade do trabalho na indústria de celulose (MONTEBELLO, 2013).

O número de empregos no setor da celulose no Brasil, em 2015, era de 15.893, e no setor de papel 41.998; já o montante de salários pagos foi de $\mathrm{R} \$ 1,1$ bilhão e 1,6 bilhões, respectivamente. Mesmo tendo mais que o dobro de empregos, o total de salários pagos para os trabalhadores da indústria de papel é apenas 50\% maior (FIEP, 2016). Em 2017, o setor florestal brasileiro criou 5,8 mil novas vagas de trabalho, porém, as atividades de produção florestal relacionadas ao plantio de "florestas" comerciais perderam quase 2 mil empregos formais no ano. Com relação à Klabin, em 2017, teve um volume de venda de 3,2 milhões de toneladas de papel e celulose e uma receita líquida de $\mathrm{R} \$ 8,3$ bilhões. O número de trabalhadores na companhia nesse ano era de 19.931, sendo 14.404 trabalhadores diretos, e 5.171 indiretos, além de 356 estagiários e aprendizes (KLABIN, 2017).

De 2012 a 2017, o Setor Florestal acumulou a redução de 52 mil empregos em suas companhias. Nesse período, a indústria de papel e celulose teve um crescimento acumulado de empregos de 30\% (FUNCHAL, 2017). A queda do número de empregos principalmente na silvicultura pode ser relacionada ao extraordinário desenvolvimento 
tecnológico das máquinas agrícolas do setor, que está substituindo o trabalho humano. O Presidente do Sindicato dos Trabalhadores Rurais de Telêmaco Borba, Albani Betim, relata em relação à contratação de pessoal na silvicultura pela Klabin na região do Território que "a empresa não contrata mais ninguém praticamente. Hoje o operador faz tudo. Serviço que fazia com 500, 600 pessoas, hoje faz com 100” (BETIM, 2018).

Outro aspecto ligado às relações de trabalho é a reforma trabalhista, sancionada pelo então presidente brasileiro Michel Temer, em julho de 2017, que dá mais segurança jurídica para as empresas contratarem outras firmas para prestação de serviços. A terceirização é uma realidade que já existia no setor florestal e agora passou a ser impulsionada. Segundo Betim (2018), os terceirizados ganham menos que os contratados diretos da Klabin, muitos são trabalhadores temporários, e as condições de trabalho pioraram: “O cara que pega só o salário, o piso regional mínimo, tá passando aperto. Muitos temporários trabalham por dia, levando a marmita de casa. Sai de madrugada de casa, 5 horas tá em pé e só volta à noite”.

Estudando três empresas do setor de papel e celulose, Chagas e Machado (2012) concluíram que existe uma tendência de distribuição do valor adicionado do setor, porém, o principal beneficiário foi o capital financeiro através de suas instituições, situação que pode ser explicada pela utilização de recursos externos para financiamento da atividade. Já os governos e os acionistas detêm a menor distribuição do valor adicionado do setor.

Pode-se analisar o desempenho econômico do município de Imbaú, que, com exceção de Telêmaco Borba, é o município com maior área proporcional de silvicultura. O valor adicionado bruto da administração, defesa, educação e saúde pública e seguridade social do município em 2015 foi de $\mathrm{R} \$$ 73,06 milhões, 3,6 vezes maior que o valor adicionado bruto da agropecuária (R\$ 19,95 milhões), e 3 vezes maior que o valor adicionado bruto da indústria (R $\$ 24,37$ milhões) (IBGE, 2015). Em 2010, 29,46\% das pessoas ocupadas em Imbaú trabalhavam no setor agropecuário e a renda média per capita era de $\mathrm{R} \$ 418,52$. Já em Telêmaco Borba, apenas $0,14 \%$ trabalhavam no setor agropecuário, porém, 20\% trabalhavam na indústria. A renda per capita média de Telêmaco Borba, em 2010, era de R \$ 732,78.

Para abastecer as duas fábricas da Klabin no Território Caminhos do Tibagi, a empresa colhe e transporta diariamente 30.000 toneladas de madeira, o que equivale ao corte diário de 250 hectares. Para transportar toda essa madeira, estima-se que seja 
necessário entre 800 a 900 caminhões, sendo que grande parte destes caminhões são terceirizados.

No caso do Território Caminhos do Tibagi, apesar da maior parte da produção de madeira da Klabin ser própria, foram detectadas através de alguns contratos entre proprietários de terra e a empresa, além de conversas com trabalhadores do setor, duas modalidades de fomento: uma é referente somente ao fornecimento de mudas, e outra ao fornecimento de mudas, implantação da monocultura e um ano de manejo (modalidade empreendimento). Os contratos entre a Klabin e os fomentados preveem que na colheita o fomentado repasse parcela da produção para a empresa.

Na modalidade do fomento empreendimento, consta nos contratos que o agricultor ou empresário rural detentor da terra ficará com $45 \%$ a $55 \%$ da produção de madeira, e a outra parte será da Klabin. O produtor tem a opção de vender sua parte para a própria Klabin ou para outro comprador. Para Soares et al. (2010), as modalidades de fomento são consideradas modelos de integração, que são fundamentados em contratos de parcerias entre as empresas e agricultores.

Diesel et al. (2006), Pedrão (2004) e Pedreira (2004) afirmam que as vantagens para as empresas no fomento para o plantio de eucaliptos consistem na diminuição de despesas referentes à fiscalização; redução de investimento imobilizado, pela opção de não comprar terras; transferência de monitoramento, proteção contra roubo das plantações e outros riscos aos agricultores; e isenção de responsabilidade trabalhista ou ambiental, que no fomento recai sobre o proprietário das terras. Segundo Betim (2018), o fomento também contribui para a desorganização dos trabalhadores, já que "os fomentados não se sindicalizam".

Para Fernandes (2009), a subalternização dos agricultores, promovida pelo capital (agronegócio) através da terceirização da sua produção, ou da expropriação através da verticalização, que controla todas as suas etapas, é um modo de expandir seu território e se territorializar.

Em audiência ocorrida em setembro de 2017, em Imbaú, após a exposição do autor deste trabalho em relação ao avanço espacial do reflorestamento de exóticas no Território Caminhos do Tibagi, e também dos resultados do êxodo rural para o mesmo período das últimas duas décadas, o representante do Sindicato das Indústrias de Papel e Celulose do Paraná (SINPACEL) pediu a palavra para afirmar, conforme a exposição, que o interesse 
do deslocamento da indústria para o Brasil se dava pela abundância de terra, condições climáticas e mão de obra barata. Mas agora discordando do autor desse trabalho, o representante do SINPACEL colocou que o setor promove desenvolvimento, uma vez que Ortigueira e Imbaú, municípios mais influenciados pelo setor recentemente, melhoraram seus Índices de Desenvolvimento Humano, como pode-se verificar na Tabela 2.

Tabela 2: IDH-M de 2000 e 2010 dos municípios do Território Caminhos do Tibagi, e suas posições no ranking nacional

\begin{tabular}{lllll}
\hline \multirow{2}{*}{ Município } & \multicolumn{2}{c}{ IDH-M } & \multicolumn{2}{c}{ RANKING NACIONAL } \\
\cline { 2 - 5 } Curiúva & $\mathbf{2 0 0 0}$ & $\mathbf{2 0 1 0}$ & $\mathbf{2 0 0 0}$ & $\mathbf{2 0 1 0}$ \\
\hline Figueira & 0,482 & 0,656 & $3462^{\circ}$ & $2986^{\circ}$ \\
\hline Imbaú & 0,555 & 0,677 & $2419^{\circ}$ & $2503^{\circ}$ \\
\hline Ortigueira & 0,521 & 0,622 & $2947^{\circ}$ & $3653^{\circ}$ \\
\hline Reserva & 0,472 & 0,609 & $3609^{\circ}$ & $3927^{\circ}$ \\
\hline Tamarana & 0,485 & 0,618 & $3427^{\circ}$ & $3735^{\circ}$ \\
\hline Telêmaco Borba & 0,504 & 0,621 & $3173^{\circ}$ & $3680^{\circ}$ \\
\hline Tibagi & 0,644 & 0,734 & $717^{\circ}$ & $920^{\circ}$ \\
\hline Ventania & 0,522 & 0,664 & $2935^{\circ}$ & $2802^{\circ}$ \\
\hline \multicolumn{5}{c}{ Fonte: IBGE, 2000, 2010. } \\
\multicolumn{5}{c}{ Org: MAZER,2018 } \\
\hline
\end{tabular}

O posicionamento do representante do setor foi verdadeiro, pois houve melhora do IDH nos municípios citados, assim como em todos os outros municípios do Território. No entanto, apenas dois municípios do Território (Curiúva e Tibagi) sobem posições no Ranking Nacional, e apenas o município de Telêmaco Borba se encontra pouco acima da média nacional. Observa-se que houve um crescimento generalizado no IDH do Brasil, que passou de 0,612, em 2000, para 0,727, em 2010, classificado então como "alto" (entre 0,700 e 0,799), posicionando o país na $85^{\mathrm{a}}$ posição de IDH global (Atlas do Desenvolvimento Humano no Brasil, 2013). Portanto, não se pode afirmar que a melhora desse índice esteja atrelada diretamente à expansão do agronegócio florestal, mas a uma conjuntura nacional de melhora desse índice.

Contudo, se por um lado o PIB e o IDH-M de Telêmaco Borba transparecem uma prosperidade econômica decorrente principalmente das atividades da Indústria Klabin, a cidade também tem o título de uma das mais violentas do interior do Estado do Paraná, estando na $12^{\mathrm{a}}$ posição estadual na taxa de homicídios, e em $265^{\circ}$ lugar no ranking 
nacional (Diário dos Campos, 2016). O que se observa é que a desigualdade social, a pobreza e a exclusão social impulsionam sim a violência, já que a criminalidade se mostra como um canal mais rápido de se alcançar a mobilidade social (PINHEIR0, 1998).

Ao detalhar as informações conforme Tabela 3, pode-se observar que a situação social dos indivíduos desse Território muitas vezes é ocultada e escamoteada pelos índices de crescimento econômico que a classe dominante ostenta, não somente para impor o seu modelo de desenvolvimento, mas também para impor seu modelo como um ideal de desenvolvimento.

Tabela 3: Nível de pobreza e escolaridade da população do Território Caminhos do Tibagi - 2010

\begin{tabular}{lccc}
\hline Município & Pobres (\%) & $\begin{array}{c}\text { Extremamente } \\
\text { pobres (\%) }\end{array}$ & $\begin{array}{l}\text { Fundamental } \\
\text { incompleto e } \\
\text { analfabetos } \\
(\boldsymbol{\%})\end{array}$ \\
\hline Curiúva (PR) & 12,05 & 3,3 & 17,5 \\
\hline Figueira (PR) & 9,41 & 1,82 & 17,7 \\
\hline Imbaú (PR) & 15,5 & 4,91 & 21 \\
\hline Ortigueira (PR) & 23,38 & 6,92 & 23 \\
\hline Reserva (PR) & 20,38 & 4,87 & 18,9 \\
\hline Tamarana (PR) & 22,57 & 9,76 & 18,8 \\
\hline $\begin{array}{l}\text { Telêmaco Borba } \\
\text { (PR) }\end{array}$ & 7,05 & 2,53 & 9,3 \\
\hline Tibagi (PR) & 16,14 & 4,69 & 15,6 \\
\hline Ventania (PR) & 13,81 & 3,95 & 19,4 \\
\hline \multicolumn{2}{c}{ Fonte: IBGE (2010). } \\
\multicolumn{2}{c}{ Org: MAZER, 2018. } &
\end{tabular}

Cazella (2008) defende que a economia não é suprema, e sim que a qualidade de vida dos atores deve ser o cerne do processo de desenvolvimento. A situação desigual que o acúmulo de riquezas que um setor econômico promove em detrimento da pobreza de uma parcela significativa da população acaba por gerar falta de perspectiva de um futuro digno, sensação bem simbolizada no depoimento de um agricultor atingido pelo Deserto Verde, da região de Areia Preta, município de Imbaú, citado por Souza (2013):

“Contamos mais ou menos as casa que tem hoje, e na outra reunião passada, o pessoal mais antigo falô que, mais o menos umas 15 famílias tinha ido embora, da região, e hoje, eu contei que mora lá é só 12 famílias. Pra vocês vê como que tá a situação lá na Areia Preta." 
Diante da expansão irrefreável do reflorestamento, o êxodo rural se apresenta como uma alternativa, assim como mostra a Tabela 4.

Tabela 4: População rural do Território Caminhos do Tibagi em 1991, 2000, e 2010.

\begin{tabular}{|c|c|c|c|c|c|c|}
\hline \multirow{2}{*}{ Município } & \multicolumn{2}{|c|}{$\begin{array}{c}\text { População rural } \\
(1991)\end{array}$} & \multicolumn{2}{|c|}{$\begin{array}{c}\text { População rural } \\
(\mathbf{2 0 0 0 )}\end{array}$} & \multicolumn{2}{|c|}{$\begin{array}{c}\text { População rural } \\
(\mathbf{2 0 1 0})\end{array}$} \\
\hline & (Abs.) & $(\%)$ & (Abs.) & $(\%)$ & (Abs.) & $(\%)$ \\
\hline Curiúva & 6.514 & 62,02 & 5.878 & 45,55 & 4.350 & 31,24 \\
\hline Figueira & 2.405 & 25,09 & 1.396 & 15,45 & 1.202 & 14,49 \\
\hline Imbau & 4.219 & 52,86 & 3.991 & 42,13 & 4.214 & 37,38 \\
\hline Ortigueira & 22.092 & 80,32 & 16.853 & 66,83 & 13.793 & 58,99 \\
\hline Reserva & 16.708 & 69,91 & 14.366 & 59,92 & 12.966 & 51,51 \\
\hline Tamarana & 4.567 & 52,94 & 4.994 & 51,42 & 6.404 & 52,23 \\
\hline Tibagi & 9.380 & 57,12 & 8.155 & 44,24 & 7.676 & 39,68 \\
\hline $\begin{array}{l}\text { Telêmaco } \\
\text { Borba }\end{array}$ & 7.279 & 12,51 & 2.884 & 4,71 & 1.432 & 2,05 \\
\hline Ventania & 2.913 & 45,98 & 2.667 & 33,24 & 3.446 & 34,61 \\
\hline
\end{tabular}

Org: MAZER, 2018.

À medida que o reflorestamento avança no território, os agricultores estão indo embora do meio rural. Não se pode afirmar que o agronegócio florestal seja o único responsável pelo êxodo rural do Território Caminhos do Tibagi, mas, como modelo hegemônico de produção, geração e concentração de riqueza, é um dos maiores responsáveis por esse fenômeno.

Pode-se entender que "ao se apropriar de um espaço, concreta ou abstratamente, o ator territorializa o espaço" (RAFFESTIN, 1993, p.143). Com a territorialização, vem a desterritorialização, que, dentre tantos outros vieses, pode ser entendida como uma limitação do acesso à terra, entendida essa como local de apropriação simbólica, não só em seu sentido físico e material (HAESBAERT, 2003).

O processo de desterritorialização dos camponeses também pode ser evidenciado pela concentração de terras da última década no Território Caminhos do Tibagi. Os dois últimos censos agropecuários (Tabela 5) demonstram como diminuiu a quantidade de estabelecimentos rurais nos municípios do Território. 
Tabela 5: Quantidade de estabelecimentos rurais em 2006 e 2017, por extrato, nos municípios do Território Caminhos do Tibagi- PR

\begin{tabular}{lllllllll}
\hline Município & $\begin{array}{c}\text { Estabelecimentos } \\
\text { até } \mathbf{1 0} \text { ha }\end{array}$ & \multicolumn{2}{c}{$\begin{array}{c}\text { Estabelecimentos } \\
\text { de } \mathbf{1 0} \text { a 50 ha }\end{array}$} & $\begin{array}{c}\text { Estabelecimen- } \\
\text { tos de 50 a 200 } \\
\text { ha }\end{array}$ & $\begin{array}{c}\text { Estabelecimen- } \\
\text { tos acima de } \\
\text { 200 ha }\end{array}$ \\
\hline Curiuva & 2006 & 2017 & 2006 & 2017 & 2006 & 2017 & 2006 & 2017 \\
\hline Figueira & 142 & 417 & 328 & 345 & 70 & 103 & 32 & 46 \\
Imbau & 306 & 376 & 75 & 89 & 29 & 27 & 13 & 11 \\
Ortigueira & 1634 & 1180 & 163 & 156 & 47 & 29 & 15 & 19 \\
Reserva & 900 & 526 & 885 & 1303 & 324 & 275 & 32 & 46 \\
Tamarana & 559 & 256 & 427 & 258 & 74 & 53 & 53 & 30 \\
Tibagi & 469 & 432 & 422 & 313 & 158 & 121 & 185 & 171 \\
Telêmaco & 93 & 76 & 14 & 9 & 7 & 7 & 4 & 2 \\
Borba & & & & & & & & \\
Ventania & 176 & 177 & 427 & 258 & 56 & 50 & 48 & 45 \\
Total & $\mathbf{4 5 7 1}$ & $\mathbf{3 6 3 7}$ & $\mathbf{4 0 3 8}$ & $\mathbf{3 4 0 8}$ & $\mathbf{1 0 2 2}$ & $\mathbf{8 4 2}$ & $\mathbf{4 8 4}$ & $\mathbf{4 6 0}$ \\
\hline
\end{tabular}

Fonte: Censo Agropecuário $(2006,2017)$.

Org: MAZER, 2018.

Em 2006 o Território Caminhos do Tibagi tinha 10.115 estabelecimentos rurais, ao passo que 2017 constatou-se 8.347 , uma diminuição de $18 \%$, sendo mais acentuada essa redução no extrato de estabelecimentos de até 10 ha - $21 \%$, e menos acentuada no extrato de estabelecimentos acima de 200 ha - 5\%. O estado do Paraná nesse período registrou uma redução de $17,77 \%$ no número de estabelecimentos rurais.

\section{Territórios em disputa entre camponeses e o agronegócio florestal}

Para Fernandes (2009), os modelos de desenvolvimento do agronegócio e do campesinato formam territórios divergentes, nessa situação com três tipos de paisagens:

[...] a do território do agronegócio que se distingue pela grande escala e homogeneidade da paisagem, caracterizado pela desertificação populacional, pela monocultura e pelo produtivismo para a exportação; o território camponês que se diferencia pela pequena escala e heterogeneidade da paisagem geográfica, caracterizado pelo frequente povoamento, pela policultura e produção diversificada de alimento - principalmente - para o desenvolvimento local, regional e nacional; o território camponês monopolizado pelo agronegócio, que se distingue pela escala e homogeneidade da paisagem geográfica, e é caracterizado pelo trabalho subalternizado e controle tecnológico das commodities que se utilizam dos territórios camponeses. (FERNANDES, 2009, p.296). 
Esse modelo de desenvolvimento imposto pelo agronegócio vem ocasionando uma série de conflitos desde a década de 1930 no Território, aprofundando-se na década de 1960 com a Revolução Verde, e fazendo emergir nos últimos anos uma categoria social, na medida em que esses atingidos se organizam e identificam os principais conflitos que afetam seu cotidiano, seu modo de vida, sua situação social, econômica e a dinâmica desse Território. Esses sujeitos, em 2012, passam a se intitular de Comissão Regional dos Atingidos pelo Deserto Verde (CRADE). Esse movimento social juntamente com uma equipe do Instituto Federal do Paraná (IFPR), através da metodologia de auto cartografia social, elaboraram um estudo no município de Imbaú, que resultou em um Boletim Informativo onde estão sistematizados, a partir da visão dos atingidos, os conflitos socioambientais e violações dos direitos humanos nas comunidades (SOUZA, 2013).

Dentre as situações de conflitos encontradas nas comunidades estão: nascentes secas; diminuição de água do rio; envenenamento da água; diminuição de animais silvestres; retirada de mata nativa; diminuição dos peixes; substituição de plantio de alimentos por madeira; impedimento da luz solar; empobrecimento da terra; confinamento de famílias/comunidades; canos na fiação elétrica; êxodo Rural/casas abandonadas; estrago e perigo nas estradas; desaparecimento/morte de abelhas (SOUZA, 2013). O Boletim também apresenta como conquistas do movimento: Mapeamento Social dos Conflitos; Elaboração de Lei Municipal; Elaboração de Lei Estadual; Organização da CRADE; Proposta de Seminário Regional dos Atingidos pelo Deserto Verde; Valorização dos Camponeses e da cultura local; Levar para as escolas essas informações; Denúncia da violação dos direitos humanos fundamentais (SOUZA, 2013).

Após ampla mobilização popular para o lançamento do Boletim no $1^{\circ}$ Seminário Regional dos Atingidos pelo Deserto Verde, foi elaborado um projeto de lei de iniciativa popular para disciplinar o plantio de pinus e eucalipto para o município de Imbaú, apresentado na Câmara de Vereadores do município em 2014, sob amplo apoio popular. Fato ainda carente de esclarecimentos para os agricultores e integrantes do Movimento é que o projeto de lei foi aprovado e posteriormente a Lei foi arquivada.

O movimento também ampliou a articulação e seu raio de ação passando a sugerir o ordenamento do plantio de exóticas, através de projeto de lei também na Assembleia Legislativa do Paraná, em 2014. Alguns poucos deputados se envolveram nesta pauta. A 
narrativa do agronegócio florestal é muito atraente pelo seu viés de crescimento econômico, fato este que pode justificar a falta de apelo para os agentes políticos, uma vez que entrar nessa disputa para estar ao lado dos marginalizados pelo modelo de desenvolvimento vigente é estar contra a classe dominante, os detentores do poder econômico, os mesmos que estão há gerações financiando campanhas eleitorais, para também deter o poder político. A atitude de ordenar o modelo de desenvolvimento vigente parece ser ousado demais para a institucionalidade.

Dentro de todo esse contexto, o curso de Agroecologia do IFPR de Telêmaco Borba foi fechado. Os professores responsáveis por coordenar as pesquisas junto ao Movimento foram transferidos para outros campi. Segundo lideranças dos movimentos sociais da região é muito provável que as decisões tomadas pelos dirigentes do IFPR tenham sido influenciadas pela disputa de interesses envolvendo a Klabin e o Movimento.

Tais lideranças acreditam que esse processo de mobilização garantiu alguns avanços em relação às suas reivindicações. Isso ficou explícito na audiência realizada em Imbaú no dia 29 de setembro de 2017, quando em algumas falas de representantes das comunidades havia o reconhecimento de que a Klabin estava se adequando em suas áreas, ao menos para evitar queda de energia decorrente de queda de árvores, proteção de nascentes e incentivos à produção de orgânicos através de alguns projetos. Porém, alguns conflitos são inerentes a esse modelo de desenvolvimento e, portanto, o Movimento segue reivindicando. Apresentou na denominada Carta de Imbaú as seguintes resoluções: Fortalecer a resistência e as lutas locais contra as monoculturas que invadem as terras da agricultura familiar, camponesa e indígenas; Aprovação de Leis Estaduais e Municipais que disciplinem as plantações industriais; Exigir do Estado do Paraná a realização de licenciamentos ambientais e Zoneamento ecológico-econômico das Plantações Industriais de Madeira; Criação de uma Frente Parlamentar na Assembleia Legislativa do Paraná visando à defesa da Agricultura.

A terra tem centralidade na disputa do território, e, nesse aspecto, o agronegócio não avança sem resistência no Território Caminhos do Tibagi. Assentamentos da Reforma Agrária estão presentes em seis dos nove municípios do Território, e contabilizam um total de 28 Projetos de Assentamentos, com 1.014 famílias assentadas em 2017, representando uma área de mais de 28.000 ha. O modelo de desenvolvimento do agronegócio é excludente, concentra terra e acumula riqueza para uma minoria. De 
maneira antagônica, a Reforma Agrária defendida pelo Movimento dos Trabalhadores Sem Terra (MST) quer democratizar o acesso à terra e promover outros tipos de relações sociais e do homem com a terra, através da Agroecologia.

Outras estratégias dos camponeses também estão presentes no âmbito da disputa do território imaterial, a partir de suas histórias, costumes, práticas produtivas, saberes, organizações, cultura, dinâmicas políticas e sociais, enfim, em todas as dimensões da vida de seus territórios. Existem duas iniciativas de maior alcance e que têm proporcionado pertença entre os camponeses e seus territórios: as Feiras de Sementes Crioulas, que vêm ocorrendo anualmente há cinco anos, e a Rede Ecovida de Agroecologia, que dentre outras coisas, organiza grupos de agricultores inseridos na produção orgânica para certificação, comercialização e formação.

Porém, depois de 2013, com o arrefecimento da mobilização em torno da CRADE e com R \$ 30 milhões financiados pelo BNDES para um ciclo de investimentos sociais que terminaram em 2017 (Klabin, 2017), a Klabin começou a se inserir nos espaços dos agricultores e movimentos sociais, através de projetos executados por ONGs contratadas pela empresa. Algumas lideranças do Movimento acreditam que os projetos são uma resposta à mobilização que vinha prejudicando a imagem da empresa: "As pessoas entenderam os impactos. Cem anos explorando sem contrapartida, agora se mexem. É preocupação com a imagem" (Liderança do MST).

As estratégias de inserção da Klabin nos espaços de agricultores são diversas: Promoção de eventos com temas relacionados às demandas dos movimentos sociais, como sementes crioulas, proteção de nascentes, certificação da produção orgânica, comercialização; Disponibilização de recursos para eventos; Promessa de infraestrutura; Promessa de compra de alimentos garantida. "Expectativa de gerar agroindústria para cooperativa. Depois deram pra trás, percebemos que estavam usando a gente". "Rapaz responsável da compra disse que não tem garantia, se alguém oferece mais barato, vai pegar da pessoa" (Dirigente de Cooperativa de agricultores do Território).

Por mais que exista reconhecimento de que a abordagem dos projetos em parte esteja na estratégia de desenvolvimento proposta pelos movimentos sociais e seja considerada uma vitória do CRADE, aparentemente as lideranças dos movimentos sociais têm clareza acerca da disputa do território e apresentam críticas: "Dizem que certificaram 20 famílias. Na verdade, foi trabalho da Rede e da universidade" (Dirigente de 
Cooperativa de agricultores); "IDH baixo, não desenvolveu nada, agricultura abandonada, Estado não faz nada. Uma coisa é reconhecer a contrapartida, outra é estar vinculado à empresa, tem conflito de identidade. Nós disputamo a mema coisa: terra pro nosso projeto de desenvolvimento e eles pro lucro" (Liderança do MST).

A Agroecologia é um elemento de identificação, referência e pertença dos movimentos sociais. O agronegócio florestal, além de disputar o sentido do Desenvolvimento Sustentável, sem abordar questões referentes à concentração de terras e riqueza, trata apenas de relacioná-lo à conservação ambiental e à produção orgânica de alimentos. "Não se consegue mais discutir profundamente, nem avançar com o movimento" (Integrante da CADRE); "Esparramam as condições. Se amanhã ou depois se desenvolver, quem vai ser?" (Liderança do MST).

Agroecologia, na dimensão social, tem como horizonte a distribuição da produção e dos custos, a segurança e soberania alimentar; a dimensão cultural deve reconhecer os saberes e conhecimentos locais, respeitando suas prerrogativas no desenho do seu agrossistema; a dimensão econômica deve garantir as necessidades dos agricultores e suas famílias, diminuir os riscos da dependência do mercado e considerar todos os custos do sistema; a dimensão ecológica deve estar focada na conservação e recuperação dos recursos naturais em todos os níveis; a dimensão política deve garantir os processos democráticos e participativos no meio rural; e, por fim, a dimensão ética é indissociável da sustentabilidade, a partir de um conjunto extenso de valores (SARANDÓN; FLORES, 2014), portanto inconciliável com o território do agronegócio.

\section{Considerações finais}

O agronegócio florestal se expandiu sobre o Território Caminhos do Tibagi a partir da instalação da fábrica de papel e celulose do grupo Klabin no município de Telêmaco Borba. O Estado teve e tem papel fundamental na expansão do setor de papel e celulose na região e no país, bem como o território em estudo apresenta condições que garantem competitividade para o setor, através da exploração das terras, recursos naturais e força de trabalho.

O agronegócio florestal territorializa o Território Caminhos do Tibagi, através do plantio de monoculturas de espécies florestais exóticas para produção de papel e celulose. O avanço das áreas de reflorestamento produz impactos ambientais e socioeconômicos, 
promovendo um modelo de desenvolvimento fundamentado na concentração de riquezas e terras, e desterritorialização dos camponeses.

De outro lado, os territórios camponeses resistem em suas comunidades e assentamentos da reforma agrária, promovendo um modelo de desenvolvimento alternativo com base na Agroecologia, e outros modos de relações sociais com a terra e com a natureza.

\section{REFERÊNCIAS}

ATLAS BRASIL. Atlas do Desenvolvimento Humano no Brasil: Ranking Paraná 2010. PNUD, Ipea, FJP, 2013. Disponível em: http://www.atlasbrasil.org.br. Acesso em: 17 jul. 2018.

\section{BANCO NACIONAL DE DESENVOLVIMENTO ECONÔMICO E SOCIAL.} BNDES aprova financiamento de $\mathbf{R}$ \$ 1,7 bilhão para a Klabin. 08 ago. 2006. Disponível em: https://www.bndes.gov.br/wps/portal/site/home/imprensa/noticias/conteudo/20060808_ not138_06. Acesso em: 20 out. 2018.

\section{. Com financiamento de $\mathrm{R} \$ \mathbf{3 , 3 7}$ bi e subscrição de debêntures, BNDES} responde por $54 \%$ do investimento total de nova fábrica da Klabin. 28 jun. 2016. Disponível em:

https://www.bndes.gov.br/wps/portal/site/home/imprensa/noticias/conteudo/comfinanciamento-de-r-3-37-bi-e-subscricao-de-debentures-bndes-\%20responde-por-54-doinvestimento-total-de-nova-fabrica-da-klabin. Acesso em: 20 out. 2018.

BETIM, Albani. Albani Betim: depoimento [set. 2018]. Entrevistador: Guilherme Pedrollo Mazer. Telêmaco Borba: Sede do Sindicato dos Trabalhadores Rurais de Telêmaco Borba e Regão, 2018. Entrevista concedida ao autor.

BRASIL. Secretaria de Desenvolvimento Territorial - Ministério do Desenvolvimento Agrário. Perfil Territorial: Caminhos do Tibagi - PR, 2015. Disponível em: http://sit.mda.gov.br. Acesso em: 16 set. 2018.

CASTELlA, Paulo Roberto; BRITEZ, Ricardo Miranda. (Orgs.) A Floresta com Araucária no Paraná: conservação e diagnóstico dos remanescentes florestais. Brasília: MMA, 2004.

CHAGAS, Rogério Rocha das; MACHADO, Julio Henrique. Geração e distribuição de valor adicionado no setor de papel e celulose. Revista de Iniciação Científica da Libertas, São Sebastião do Paraíso, v.2, n.2, p. 70-84, dez. 2012. Disponível em: http://www.libertas.edu.br/revistas/index.php/riclibertas/article/view/29/27. Acesso em: 03 set. 2018. 
CUNHA, Anacília Carneiro da. O Homem Papel: Análise Histórica do Trabalhador das Indústrias Klabin do Paraná de Celulose S/A 1942-1980.1982. 212 p. Dissertação (Mestrado em História do Brasil) - Curso de Pós-Graduação em História Econômica, Universidade Federal do Paraná, Curitiba, 1982. Disponível em: https://acervodigital.ufpr.br/bitstream/handle/1884/24603/D\%20$\%$ 20CUNHA,\%20ANACILIA\%20CARNEIRO\%20DA.pdf?sequence=1. Acesso em: 21 ago. 2018.

DELGADO, Guilherme C. Expansão e modernização do setor agropecuário no pósguerra: um estudo da reflexão agrária. Estud. Av., São Paulo, v.15, n.43, p. 157-172, dez. 2001. Disponível em:

http://www.scielo.br/scielo.php?script=sci_arttext\&pid=S0103-

$40142001000300013 \& \operatorname{lng}=e n \& n r m=$ iso. Acesso em: 03 set. 2018.

. A questão agrária no Brasil, 1950-2003. In: JACCOUD, Luciana. Questão

social e políticas sociais no Brasil contemporâneo. Brasília: Ipea, 2005. p. 51-90.

DIESEL, Vivien et al. Os impactos sociais dos programas de fomento florestal. Rev. Extensão Rural. Santa Maria, v. 13, p. 120-146, 2006.

FEDERAÇÃO DAS INDÚSTRIAS DO ESTADO DO PARANÁ. Panorama setorial: indústria de celulose, papel, embalagens e artefatos de papel - Paraná 2016. Curitiba: FIEP, 2016. Disponível em: http://www.fiepr.org.br/para-sindicatos/estudoseconomicos/uploadAddress/papel_digital[75083].pdf. Acesso em: 25 jul. 2018.

FERNANDES, Bernardo Mançano. Sobre a Tipologia de Territórios. In: Saquet, Marco Aurélio; Sposito, Eliseu Saverio. (Org.). Territórios e territorialidades: teorias, processos e conflitos. São Paulo: Expressão Popular, 2009.

FONSECA, Maria da Graça Derengowski. Indústria de Papel e Celulose no Brasil: Um Estudo sobre Competitividade e Meio Ambiente. Informações Econômicas, São Paulo, v.25, n.10, p.11-32, out. 1995. Disponível em:

http://www.iea.sp.gov.br/ftpiea/ie/1995/tec1-1095.pdf. Acesso em: 01 set. 2018.

FUNCHAL, Márcio. Evolução dos empregos no Brasil e no setor florestal._Revista O Papel. Dez. 2017. Disponível em:

http://www.sinpacel.org.br/informativos/2017/703/evolucao-dos-empregos-no-brasil-eno-setor-florestal.pdf. Acesso em: 01 out. 2018.

HAESBAERT, Rogério. Da Desterritorialização à Multiterritorialidade. [In: Boletim Gaúcho de Geografia. jan. 2003, p. 22].

HILGEMBERG, Emerson Martins; BACHA, Carlos José Caetano. A evolução da indústria brasileira de celulose e sua atuação no mercado mundial. Análise Econômica, Porto Alegre, A.19, n.36, p.67-92, 2001. Disponível em:

http://seer.ufrgs.br/index.php/AnaliseEconomica/article/view/10679/6308. Acesso em: 04 set. 2018. 
HOFFMANN, Rodolfo; KAGEYAMA, Angela A. Modernização da agricultura e distribuição da renda no Brasil. Pesquisa e Planejamento Econômico, Brasília: IPEA, v.15, n.1, p. 171-208, abr. 1985. Disponível em:

http://repositorio.ipea.gov.br/bitstream/11058/6148/1/PPE_v15_n01_Modernizacao.pdf. Acesso em: 03 mar. 2018.

HUPALO, Marcelo. Marcelo Hupalo: depoimento [set. 2018].

Entrevistador: Guilherme Pedrollo Mazer. Ponta Grossa: Laboratório de Mecanização Agrícola/UEPG, 2018. Entrevista concedida ao autor.

INSTITUTO BRASILEIRO DE GEOGRAFIA E ESTATÍSTICA. Censo 2000: resultados. Disponível em: https://sidra.ibge.gov.br/pesquisa/censodemografico/demografico-2000/inicial. Acesso em: 18 jun. 2018.

Censo 2010: resultados. Disponível em:

https://sidra.ibge.gov.br/pesquisa/censo-demografico/demografico-2010/inicial. Acesso em: 18 jun. 2018.

Censo Agropecuário 2017. Disponível em:

https://censos.ibge.gov.br/agro/2017/. Acesso em: 18 jun. 2018.

Produto Interno Bruto dos Municípios 2002 - 2015. Disponível em:

https://sidra.ibge.gov.br/pesquisa/pib-munic/tabelas. Acesso em: 22 ago. 2018.

INSTITUTO PARANAENSE DE DESENVOLVIMENTO ECONÔMICO E SOCIAL. Diagnóstico socioeconômico do Território Caminhos do Tibagi: 1. ${ }^{a}$ fase:

caracterização global. Curitiba: IPARDES, 2007. 132p. Disponível em:

http://www.ipardes.gov.br/biblioteca/docs/territorio_caminhos_tibagi.pdf. Acesso em: 20 ago. 2018.

KLABIN. Linha do tempo 2016. Disponível em: https://www.klabin.com.br/pt/aklabin/memoria-klabin/linha-do-tempo/. Acesso em: 30 jul. 2018.

. Relatório de Sustentabilidade 2014. Disponível em:

http://rs2014.klabin.com.br/pt/contribuir. Acesso em: 31 jul. 2018.

Relatório de Sustentabilidade 2017. Disponível em: http://rs.klabin.com.br/. Acesso em: 30 jul. 2018.

Resumo Público 2017. Disponível em:

https://www.klabin.com.br/media/2339/resumo_pr_2017.pdf. Acesso em: 04 out. 2018.

LIMA-TOIVANEN, Maria Barbosa. A evolução da indústria sul-americana de celulose e papel: foco no Brasil, Chile e Uruguai. Revista O Papel, v. 74, n.9, p. 51-66, set. 2013. Disponível em: http://www.revistaopapel.org.br/noticiaanexos/1380634191_6d5aac0f077350b8c8a7820ccbd798db_189840160.pdf. Acesso em: 03 set. 2018. 
MARGALHO, Maurício Gonçalves. Klabin: os empresários, a empresa e as estratégias de construção da hegemonia (1930-1951). 2008. 195p. Dissertação (Mestrado em História) - Curso de Pós-Graduação em História, Universidade Federal Fluminense, Niterói, 2008. Disponível em: http://www.historia.uff.br/stricto/teses/Dissert2008_MARGALHO_Mauricio_Goncalves-S.pdf. Acesso em: 04 jun. 2018.

MAZER, Guilherme Pedrollo. Avanço do agronegócio florestal no Território Caminhos do Tibagi. Dissertação de Mestrado. Laranjeiras do Sul: UFFS, 2018.

MAZOYER, Marcel; ROUDART, Laurence. História das agriculturas no mundo: do neolítico à crise contemporânea. Tradução Cláudia F. Falluh Balduino Ferreira. São Paulo: UNESP; Brasília: NEAD, 2010.

MONTEBELLO, Adriana Estela Sanjuan. Impactos da reestruturação do setor de celulose e papel no Brasil sobre o desempenho de suas indústrias. Estudos

Econômicos, São Paulo, v. 43, n. 1, p. 109-137, jan./mar. 2013. Disponível em: http://www.scielo.br/scielo.php?script=sci_arttext\&pid=S010141612013000100005\&lng=en\&nrm=iso. Acesso em: 04 set. 2018.

MORO, Rosemeri Segecin. A vegetação dos Campos Gerais da escarpa devoniana. In: DITZEL, C.D.H.M.; SAHR, C.L.L. Espaço e Cultura: Ponta Grossa e os Campos Gerais. Ponta Grossa: Ed. UEPG, 2001. p. 481-503.

OLIVEIRA, Ricardo Costa de. Notas sobre a política paranaense no período de 1930 a 1945. Revista de Sociologia e Política: UFPR, n. 9, p. 47-56, 1997. Disponível em: https://revistas.ufpr.br/rsp/article/view/39297/24116. Acesso em: 20 abr. 2018.

OJALA, Jari et al. A Evolução da Indústria de Papel Global. Revista O Papel, v. 74, n. 9, p. 51-54, set. 2013. Disponível em: http://www.revistaopapel.org.br/noticiaanexos/1380633861_9d98ac5d69c82e3958cc89d10147e758_976076025.pdf. Acesso em: 13 mar. 2018.

PEDRÃO, Fernando. As transformações rurais do capital no Brasil. Rev. Bahia Análise \& Dados, v. 13, n. 4, mar. 2004.

PEDREIRA, Maria da Silva. Complexo florestal, desenvolvimento e reconfiguração do espaço rural: o caso da região do Extremo Sul baiano. Rev. Bahia Análise \& Dados, v. 13, n. 4, mar. 2004.

PINHEIRO, Paulo S. et al. São Paulo sem medo. Rio de Janeiro: Garamond, 1998. p. 133-154.

RAFFESTIN, Claude. Por uma Geografia do Poder. São Paulo: Ática, 1993. REFERÊNCIAS para uma Estratégia de Desenvolvimento Rural Sustentável no Brasil. In: Série Documentos Institucionais No 01 - SDT. Brasília: Ministério do Desenvolvimento Agrário; mar. 2005. 
RODERJAN, Carlos Vellozo et al. As unidades fitogeográficas do estado do

Paraná. Revista Ciência e Ambiente, Santa Maria, v. 24, p. 75-92, 2002.

ROSTOW, Walt W. The Stages of Economic Growth. The Economic History Review, v. 12, p. 1-16, ago. 1959. Disponível em: https://doi.org/10.1111/j.1468-

0289.1959.tb01829.x. Acesso em: 20 mai. 2018.

SARANDÓN, Santiago Javier; FLORES, Cláudia Cecília. Agroecología: bases teóricas para el diseño y manejo de Agroecosistemas sustentables. $-1^{\mathrm{a}}$ ed. - La Plata:

Universidad Nacional de La Plata, 2014. p. 13-98.

SILVA, José Graziano da. Tecnologia e agricultura familiar. Ed. 2, Porto Alegre: UFRGS, 2003.

SOARES, Naisy Silva et al. A cadeia produtiva da celulose e do papel no Brasil. Rev. Floresta, Curitiba, PR, v. 40, n. 1, p. 1-22, jan./mar. 2010.

SOUZA, Roberto Martins de (Org.). Identidades coletivas e conflitos territoriais no sul do Brasil: deserto verde no município de Imbaú. Boletim Informativo. Edição especial. Abril de 2013.

TELÊMACO Borba está entre as cidades mais violentas. Diário dos Campos, 13 nov. 2016. Disponível em: https://www.diariodoscampos.com.br/noticia/telemaco-borbaesta-entre-as-cidades-mais-violentas. Acesso em: 20 set. 2018.

TOIVANEN, Hannes. Waves of Technological Innovation: The Evolution of the U.S. Pulp and Paper Industry, 1860-2000. In: LAMBERG Juha-Antti; OJALA, Jari (eds). The Evolution of Global Paper Industry 1800-2050: A Comparative Analysis. Springer, Netherlands, 2012. p. 49-80. Disponível em:

https://www.researchgate.net/publication/263525248_Waves_of_Technological_Innova tion_The_Evolution_of_the_US_Pulp_and_Paper_Industry_1860-2000. Acesso em: 14 jul. 2018.

Recebido em 31/03/2020.

Aceito para publicação em 15/05/2020. 